\title{
Mangroves facing climate change: landward migration potential in response to projected scenarios of sea level rise
}

\author{
D. Di Nitto ${ }^{1}$, G. Neukermans ${ }^{1}$, N. Koedam ${ }^{1}$, H. Defever ${ }^{1}$, F. Pattyn ${ }^{3,4}$, J. G. Kairo ${ }^{5}$, and F. Dahdouh-Guebas ${ }^{1,2}$ \\ ${ }^{1}$ Biocomplexity Research Focus c/o Laboratory of Plant Biology and Nature Management, Mangrove Management Group, \\ Vrije Universiteit Brussel - VUB, Pleinlaan 2, 1050 Brussels, Belgium \\ ${ }^{2}$ Laboratoire d'Écologie des Systèmes et Gestion des Ressources, Département de Biologie des Organismes, Faculté des \\ Sciences, Université Libre de Bruxelles - ULB, CP 169, Avenue F.D. Roosevelt 50, 1050 Brussels, Belgium \\ ${ }^{3}$ Laboratory of Physical Geography, Vrije Universiteit Brussel, Pleinlaan 2, 1050 Brussels, Belgium \\ ${ }^{4}$ Unité de Recherche Sciences de la Terre,Université libre de Bruxelles, Brussels, Belgium \\ ${ }^{5}$ Kenya Marine and Fisheries Research Institute, P.O. Box 81651, Mombasa, Kenya
}

Correspondence to: D. Di Nitto (diana.dinitto@gmail.com)

Received: 21 December 2012 - Published in Biogeosciences Discuss.: 25 February 2013

Revised: 29 September 2013 - Accepted: 24 October 2013 - Published: 13 February 2014

\begin{abstract}
Mangrove forests prominently occupy an intertidal boundary position where the effects of sea level rise will be fast and well visible. This study in East Africa (Gazi Bay, Kenya) addresses the question of whether mangroves can be resilient to a rise in sea level by focusing on their potential to migrate towards landward areas. The combinatory analysis between remote sensing, DGPS-based ground truth and digital terrain models (DTM) unveils how real vegetation assemblages can shift under different projected (minimum $(+9 \mathrm{~cm})$, relative $(+20 \mathrm{~cm})$, average $(+48 \mathrm{~cm})$ and maximum $(+88 \mathrm{~cm}))$ scenarios of sea level rise (SLR). Under SLR scenarios up to $48 \mathrm{~cm}$ by the year 2100 , the landward extension remarkably implies an area increase for each of the dominant mangrove assemblages except for Avicennia marina and Ceriops tagal, both on the landward side. On the one hand, the increase in most species in the first three scenarios, including the socio-economically most important species in this area, Rhizophora mucronata and C. tagal on the seaward side, strongly depends on the colonisation rate of these species. On the other hand, a SLR scenario of $+88 \mathrm{~cm}$ by the year 2100 indicates that the area flooded only by equinoctial tides strongly decreases due to the topographical settings at the edge of the inhabited area. Consequently, the landward Avicennia-dominated assemblages will further decrease as a formation if they fail to adapt to a more frequent inundation. The topography is site-specific; however non-invadable areas can be typical for many mangrove settings.
\end{abstract}

\section{Introduction}

Inhabiting the interface between land and sea, mangroves are amongst one of the most at-risk ecosystems when sea level rises (McLeod and Salm 2006). Throughout the Quaternary, mangroves have shown high resilience to disruptions from large sea level fluctuations over historic timescales (Woodroffe 1990). However, adaptation probabilities strongly depend on the rates of sea level rise (SLR) and sediment supplies in combination with subsurface processes that affect sediment elevation (Gilman et al., 2007; Gilman et al., 2006; McLeod and Salm 2006; Wolanski and Chappell 1996; Woodroffe 1990). Ellison and Stoddart (1991) suggested that mangroves are stressed by SLRs of between 9 and $12 \mathrm{~cm}$ over $100 \mathrm{yr}$ and concluded that faster rates could seriously threaten mangrove ecosystems. This view has been challenged by Snedaker et al. (1994), who cited historical records showing changes nearly twice that high in mangrove expansion under relative sea level; however hard scientific data or SLR simulations are not available.

As mangrove ecosystems are very dynamic, the ability of these forests to migrate to more landward zones is a very important aspect when considering the effect of SLR on mangroves. If the possibility presents itself, mangroves will adjust to a SLR by expanding landward or laterally into areas of higher elevation, or even by growing upward in place (McLeod and Salm 2006). However, the mangrove areas that 
are most vulnerable are those situated in a physiographic setting that limits landward migration due to obstacles or steep gradients and with a net decrease in sediment elevation or sediment accretion that is insufficient to keep up with SLR (Gilman et al., 2008). Landward obstructions, artificial or natural, have an effect on ecosystems that would normally move landward in response to erosive forces. Where there is a rise in sea level relative to the land, a coastal squeeze takes place (Doody, 2004). On the species level, adaptation can occur through landward migration at different speeds as mangrove species maintain their preferred hydroperiod or by sediment accretion (Gilman et al., 2008). Mangrove species composition can strongly affect a mangrove's resistance and resilience to SLR given that, on the one hand, individual species have varying tolerances of the period, frequency and depth of inundation, and, on the other hand, different vegetation zones have different rates of change in sedimentation elevation (Krauss et al., 2003; McKee et al., 2007; Rogers et al., 2005). Furthermore, several scientists have also investigated how different functional root types of several mangrove species respond to changes in elevation in order to determine the vulnerability to SLR (Ellison and Stoddart 1991; Vincente 1989).

Species-specific competition may allow some species to outcompete others and to become more dominant within the newly formed species composition (Lovelock and Ellison, 2007). Establishment and dispersal play a significant role in these processes. They are, however, different for various species and strongly dependent on many biotic factors such as buoyancy, period of obligate dispersal, longevity and period of establishment (Allen and Krauss, 2006; Clarke et al., 2001; Drexler, 2001; Tomlinson, 1986), whilst wind and hydrodynamics of tides and currents can be equally important abiotic factors (Stieglitz and Ridd, 2001). Additionally, factors like microtopography, the soil type at the top and root structures can also have a significant effect on the fate of propagules once released from their parental tree, as can human-induced degradation, like tree cutting (Di Nitto et al., 2008).

To date, mangroves have been subjected to non-climaterelated anthropogenic stressors which have accounted for most of the global average annual rate of mangrove loss, estimated to be 1-2\%, with losses during the last quarter of a century ranging from 35 to $86 \%$ (Alongi, 2002; Duke et al., 2007; FAO 2003, 2007; Valiela et al., 2001). So far, relative SLR has been a smaller threat to mangroves. However, it may constitute a substantial proportion of predicted losses (about 10-20\% of total estimated losses) as several studies have already shown that many mangrove areas have not been keeping pace with current rates of relative SLR (Cahoon et al., 2006; Gilman et al., 2007; McKee et al., 2007). We would like to emphasise the importance of understanding mangrove responses to SLR as these ecosystems provide tremendous social, economic and ecological value (Barbier, 2003; Dahdouh-Guebas et al., 2005; Mumby et al., 2004,
Nagelkerken et al., 2008; Walters et al., 2008; Wells et al., 2006).

This study focuses on the critical factor "tidal range" in order to investigate the potential for landward migration of mangrove vegetation assemblages in Gazi Bay (Kenya) under different SLR scenarios. As mangrove species have their preferred hydroperiod, the vegetation distribution in the different inundation classes at present is extrapolated towards future SLR scenarios based on a static mangrove surface elevation. Digital terrain modelling is derived from differential GPS field measurements and used to simulate water levels in a GIS environment. In combination with a mangrove species map, preliminary results are generated regarding the effect of SLR in the study site in Gazi Bay (Kenya). The focus resides on individual mangrove species and their possible colonisation of back-mangrove areas that become accessible when sea level rises. We deliberately adopt a reductionistic approach by taking abstraction of alterations in sedimentation and elevation and other consequences of global change such as increases in temperature, $\mathrm{CO}_{2}$ concentration and storm frequency, as well as possible shifts in seasonal periods (Pernetta, 1993; UNEP, 1994; Woodroffe, 1990; Woodroffe and Grime, 1999). However we feel that, in this context, relevant conclusions can be made. First of all, this study represents the first attempt to simulate the effect of SLR based on a large amount of detailed information on topography and vegetation covering the whole bay. Secondly, many researchers have already gathered valuable information within this study area on diverse subjects like regeneration, vegetation structure dynamics, human impacts and propagule dispersal (e.g. Abuodha and Kairo, 2001; Bosire et al., 2003, 2008b; Dahdouh-Guebas Farid and Koedam, 2006; Dahdouh-Guebas et al., 2002a; Di Nitto et al., 2008; Kairo et al., 2001; Kirui et al., 2008; Neukermans et al., 2008). The latter gives us the opportunity to draw preliminary conclusions on the potential for landward migration of mangroves in Gazi Bay and to create some views on the future vegetation structure dynamics, which can contribute to their resilience to SLR. Resilience is understood here as the survival of the formation, even if displaced in space.

\section{Material and methods}

\subsection{Study area}

Gazi Bay $\left(4^{\circ} 26^{\prime} \mathrm{S}, 39^{\circ} 30^{\prime} \mathrm{E}\right)$ is a shallow tropical water system situated circa $40 \mathrm{~km}$ south of the historic port (Kilindini) of Mombasa (Fig. 1). The mangrove forest covers an area of approximately $6.5 \mathrm{~km}^{2}$ and is drained by two tidal creeks. The tidal regime within the bay is semi-diurnal with a macro tidal range of $3.5 \mathrm{~m}$ and an ebb-dominant asymmetry (Kitheka 1996, 1997). Ten East African mangrove species are present within this bay fringed with mangrove forests, seagrass beds and coral reefs, more specifically Avi- 
(A)

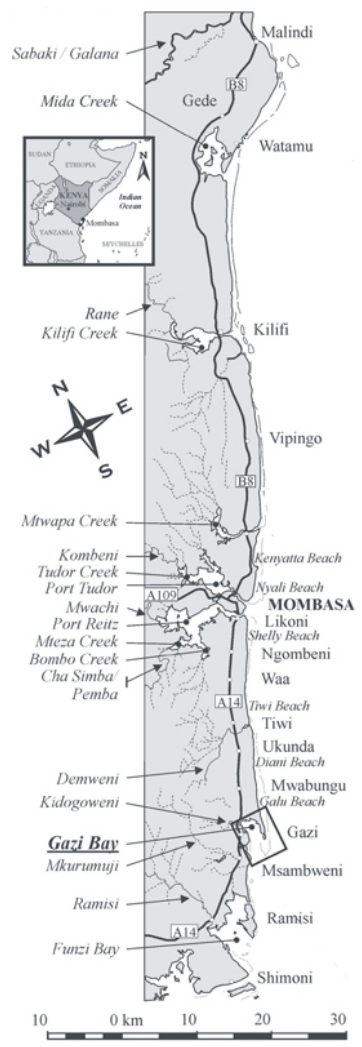

(B)

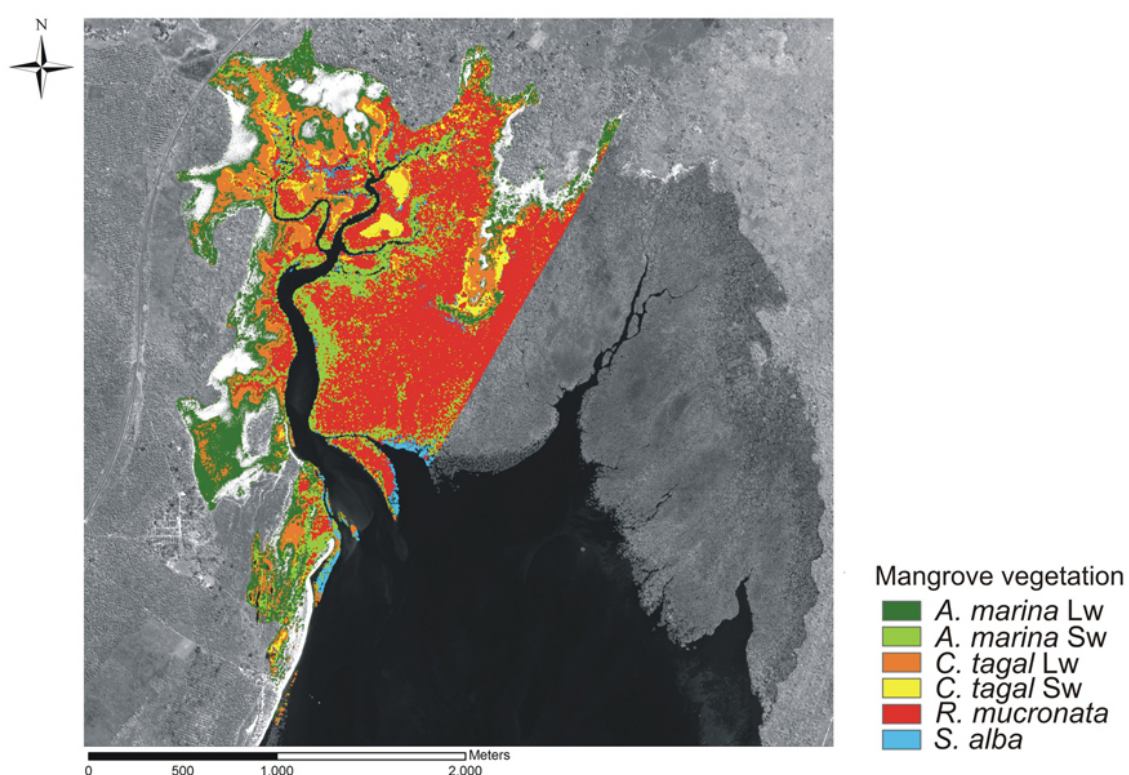

Fig. 1. Representation of (A) the Kenyan coast (Dahdouh-Guebas et al., 2000) and (B) Gazi Bay. The satellite image (QuickBird) shows the whole bay of Gazi ; however this research focuses on the western part as encompassed by the overlaid vegetation map. S. alba=Sonneratia alba, R. mucronata = Rhizophora mucronata, $C$. tagal $\mathrm{Lw}=$ Ceriops tagal on the landward side, $C$. tagal $\mathrm{Sw}=$ Ceriops tagal on the seaward side A. marina $\mathrm{Lw}=$ Avicennia marina on the landward side and A. marina $\mathrm{Sw}=$ Avicennia marina on the landward side. Classification of the mangrove species coverage was obtained by Neukermans et al. (2008).

cennia marina (Forsk.) Vierh., Bruguiera gymnorrhiza (L.) Lam., Ceriops tagal (Perr.) C. B. Robinson, Heritiera littoralis Dryand., Lumnitzera racemosa Willd., Rhizophora mucronata Lam., Sonneratia alba Sm., Xylocarpus granatum Koen, a second yet unidentified Xylocarpus species, and Pemphis acidula Forst. (Gallin et al., 1989) (nomenclature according to Tomlinson, 1986). Topographical measurements (see Sect. 2.2) were conducted throughout the western part of the bay during two dry periods (July-August 2003 and 2005).

Mangrove species distribution within this study area was obtained by Neukermans et al. (2008). A classification of a Standard QuickBird multispectral satellite image was performed in combination with ground truthing based on vegetation transects by the point-centred quarter method (PCQM+) of Dahdouh-Guebas and Koedam (2006). The two socioeconomically most important species within this study area, $R$. mucronata and C. tagal (Dahdouh-Guebas et al., 2000, 2004a), are mapped with user's accuracies above $85 \%$, whereas all four dominant mangrove species (A. marina (on the seaward side ( $\mathrm{Sw}$ ) and the landwards side (Lw)), S. alba,
R. mucronata and C. tagal ( $\mathrm{Sw}$ and $\mathrm{Lw})$ ) are mapped with an overall accuracy (OA) of $72 \%$.

\subsection{Topographical field survey and construction of a DTM}

The aim of the topographical field surveys was to construct a digital terrain model (DTM) in order to simulate water levels at present and for different Intergovernmental Panel on Climate Change (IPCC) scenarios of SLR (for explanation on IPCC scenarios, see Sect. 2.3). Measurements were carried out using a Leica GPS-AT302, which is a centimetreprecise differential global positioning system (DGPS) with a fixed reference station and a mobile rover station. Since a dense mangrove cover disrupts the DGPS signal, a stratified design was applied targeting the low-cover mangroves, back-mangrove areas, tidal mudflats and creeks. Resolution of the DTM varies from $1 \mathrm{~m}$ in the topographically "rough" areas to $50 \mathrm{~m}$ in areas characterised by a relatively flat and even surface. All DGPS points were post-processed in SKI (Static Kinematic Program), and after converting these geographical coordinates into projected coordinates (WGS 1984, 
UTM zone 37S) and assigning their absolute height, a thorough knowledge of the field was used to add extra points and breaklines in order to eventually optimise the constructed DTM. As the height measurements of these points are relative, we followed the high-water line of a chosen spring tide on two consecutive days and collected the $x y z$ data of 116 points using the DGPS. Based on the Kilindini tide tables (Kenya Ports Authority, KPA) the approximated absolute height of the water was calculated, and the relative elevations in the DTM converted to approximate absolute field topography. We recognise a temporal delay in tides between Mombasa and Gazi Bay; however this does not influence our study.

The final coordinates resulting from the topographical measurements were inserted into a geographical information system (GIS) and served as an input to create a triangular irregular network (TIN) of the area. The TIN was based on the (non-constrained) Delauney triangulation of the original set of points by use of Voronoi diagrams, a theory for which we refer to Raper (1990). In this paper it is not the intention to investigate in depth the impact of these elevation errors through principal component analysis (Lopez, 1997), but we give an estimation of the absolute mean error and the standard deviation in densely covered and less densely covered areas. After extracting 30 points from each of the latter areas, the TIN was reconstructed and height values were reassessed for these particular points.

\subsection{Spatial analyses}

IPCC has predicted several SLR scenarios $(+9 \mathrm{~cm}$ (minimum), $+20 \mathrm{~cm}$ (relative), $+48 \mathrm{~cm}$ (average) and $+88 \mathrm{~cm}$ (maximum)) by the year 2100 (IPCC 2001) ${ }^{1}$ based on atmosphere-ocean general circulation models and emission scenarios incorporating uncertainties regarding changes in terrestrial ice, permafrost and sediment deposition. The main purpose of the spatial analyses is to predict possible changes in vegetation assemblages under these different scenarios of SLR.

This modelling exercise mainly focuses on the potential of mangroves to migrate towards landward areas, but it is solely based on sea level rise relative to a static mangrove surface elevation. In this stage, data on sediment-related changes are

\footnotetext{
${ }^{1}$ We based our analysis on SLR scenarios of the IPCC Third Assessment Report (TAR) (2001) and not on those of the Fourth Assessment Report (AR4) (2007), which forecast a range from 9 to $88 \mathrm{~cm}$ by 2100 and a range from 18 to $59 \mathrm{~cm}$ by 2090-2099, respectively. The reason is the following: due to lacking of published literature, AR4 models do not include uncertainties in climate-carboncycle feedback, nor do they include the full effects of changes in ice sheet flow. The AR4 projections do, however, include a contribution due to increased ice flow from Greenland and Antarctica at the rates observed for 1993-2003, but these flow rates could increase or decrease in the future. The AR4 could have similar ranges to those of TAR if uncertainties were to be treated in the same way.
}

not available; however we do not underestimate the importance of sediment in mangrove vegetation dynamics in view of SLR.

The modelling exercise started with an assessment of the current species-related zonation or spatial structure present in Gazi Bay. First of all, the height boundaries for each inundation class according to Watson (1928) (Table 1) was defined based on the combination of the tide tables (July 2003July 2004) published by the KPA and the monthly inundation frequencies per class (Table 1). In further analysis, inundation frequencies higher than those of "class 1 " will be referred to as "class 0". Using ArcGIS 8.2, these boundaries were classified into inundation classes based on the DTM for the current scenario versus different IPCC scenarios of eustatic SLR. The relative scenario of $+20 \mathrm{~cm}$ coincides with the current trend of SLR within the long-term data set (19852003) obtained from gauge measurements by the Kenya Marine and Fisheries Research Institute at the Kilindini Port in Mombasa. This initiative is part of the Global Sea Level Observing System (GLOSS) founded by the Intergovernmental Oceanographic Commission (IOC) of UNESCO.

Secondly, an overlay between the vegetation map and the current inundation classes (Fig. 2b) gives an estimation of the vegetation surface of each species within each inundation class. To review the accuracy of the DTM and/or the classification of the vegetation, it is important to investigate whether the distribution of the species within the inundation classes deviate from a random distribution. To perform the statistical analyses, the complete area was divided into 10 equally sized blocks. Within each block the areal coverage (ha) was calculated for each species in all inundation classes of the current situation. Secondly, a KolmogorovSmirnov test was performed to compare the observed cumulative distribution function to a theoretical normal distribution, whereafter Kruskal-Wallis tests were completed to investigate whether the vegetation distribution within the inundation classes is random. Since the species concerned are not randomly distributed, extrapolations of the vegetation structure towards future IPCC scenarios of SLR were performed. The area increase (\%) of each inundation class within each scenario was calculated in relation to the current situation, whereafter these percentages were multiplied by the current vegetation area (ha).

\subsection{Sensitivity analysis}

A source of uncertainty in the input data is the DTM's absolute height, which was calibrated using Kilindini port gauge measurements. To address the sensitivity of the model to the absolute height uncertainty of the DTM, we investigated the impact of changes in the height boundaries of the inundation classes. Upper and lower height boundaries are slightly altered at a time and in a systematic manner, more specifically by an increase and decrease of these boundary intervals with 5,10 and $15 \%$ corresponding to 4,6 and $8 \mathrm{~cm}$. The 
Table 1. Inundation classes and monthly inundation frequency according to Watson (1928). Height boundaries (metres above datum) of present and future inundation classes are presented: a minimum $(+9 \mathrm{~cm})$, relative $(+20 \mathrm{~cm})$, average $(+48 \mathrm{~cm})$ and maximum $(+88 \mathrm{~cm})$ scenario is based on IPCC eustatic SLR scenarios for the year 2100. In further analysis, inundation frequencies higher than those of "class 1 " will be referred to as "class 0 ".

\begin{tabular}{|c|c|c|c|c|c|c|c|}
\hline $\begin{array}{l}\text { Inundation } \\
\text { classes }\end{array}$ & Flooded by & $\begin{array}{l}\text { Monthly } \\
\text { inundation } \\
\text { frequency }\end{array}$ & $\begin{array}{l}\text { Present } \\
\text { situation } \\
(\mathrm{m})\end{array}$ & $\begin{array}{l}\text { Minimum } \\
\text { scenario, } \\
+9 \mathrm{~cm}(\mathrm{~m})\end{array}$ & $\begin{array}{c}\text { Relative } \\
\text { scenario, } \\
+20 \mathrm{~cm}(\mathrm{~m})\end{array}$ & $\begin{array}{c}\text { Average } \\
\text { scenario, } \\
+48 \mathrm{~cm}(\mathrm{~m})\end{array}$ & $\begin{array}{l}\text { Maximum } \\
\text { scenario, } \\
+88 \mathrm{~cm}(\mathrm{~m})\end{array}$ \\
\hline 1 & All high tides (AHT) & $56-62$ & $2.10-2.60$ & $2.19-2.69$ & $2.30-2.80$ & $2.58-3.08$ & $2.98-3.48$ \\
\hline 2 & Medium high tides (MHT) & $45-56$ & $2.60-3.10$ & $2.69-3.19$ & $2.80-3.30$ & $3.08-3.58$ & $3.48-3.98$ \\
\hline 3 & Normal high tides (NHT) & $20-45$ & $3.10-3.50$ & $3.19-3.59$ & $3.30-3.70$ & $3.58-3.98$ & $3.98-4.38$ \\
\hline 4 & Spring high tides (SHT) & $2-20$ & $3.50-3.80$ & $3.59-3.89$ & $3.70-4.10$ & $3.98-4.28$ & $4.38-4.68$ \\
\hline 5 & Abnormal (equinoctial tides) (EHT) & $0-2$ & $3.80-4.20$ & $3.89-4.29$ & $4.10-4.40$ & $4.28-4.68$ & $4.68-5.08$ \\
\hline
\end{tabular}

(A) Presentation of the DTM

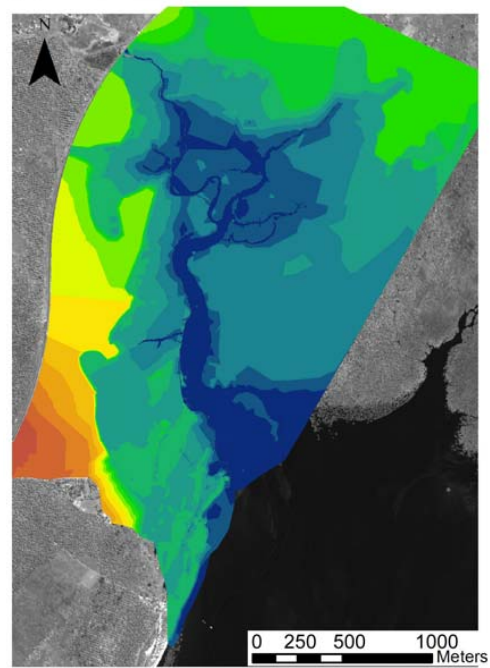

(B) 3D presentation of the combination

between

(B1) inundation classes,

(B2) vegetation map

(B3) Quickbird image

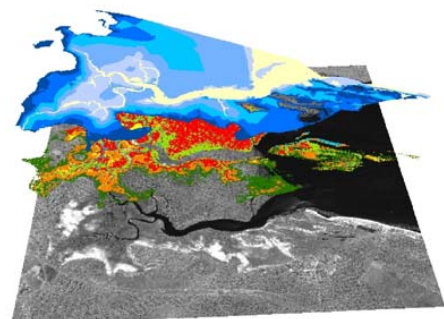

\section{$\stackrel{\wedge}{\wedge}$}
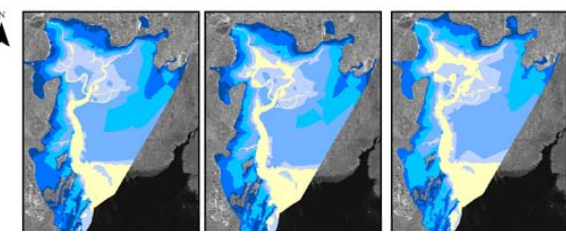

(C) Presentation of the inundation classes (SLR scenarios):

(C1) Current situation, (C2) Scenario $+9 \mathrm{~cm}$, (C3) Scenario $+20 \mathrm{~cm}$, (C4) Scenario $+48 \mathrm{~cm}$, (C5) Scenario $+88 \mathrm{~cm}$
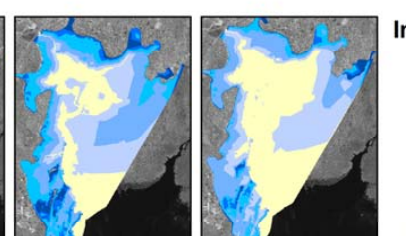

Inundation classes

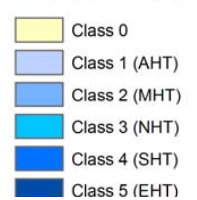

Fig. 2. (A) Presentation of the DTM. (B) 3-D presentation of the combination between (B1) inundation classes, (B2) vegetation map and (B3) QuickBird image. (C) Presentation of the inundation classes: $($ C1) current situation, $(\mathbf{C 2})$ scenario $+9 \mathrm{~cm},(\mathbf{C 3}) \mathrm{scenario}+20 \mathrm{~cm},(\mathbf{C 4})$ scenario $+48 \mathrm{~cm}$ and $(\mathbf{C 5})$ scenario $+88 \mathrm{~cm}$. AHT stands for all high tides; MHT, medium high tides; NHT, normal high tides; SHT, spring high tides; and EHT, equinoctial high tides. Inundation frequencies higher than those of "class 1" will be referred to as "class 0".

comparison between the reference map (Fig. 2C1) and the output maps after altering the height boundaries was assessed with an error matrix, giving overall (OA), user's (UA) and producer's accuracies (PA) (for calculations, see Appendix A).

\section{Results}

\subsection{Construction and validation of the digital terrain model}

The DTM of the study area is shown in Fig. 2a. After postprocessing in SKI, 4105 points were accepted with an average error on $x, y$ and $z$ of $1.16,2.08$ and $0.89 \mathrm{~cm}$, respectively, whereafter several breaklines and 82 extra points were manually added to optimise the DTM. Breaklines along the creek banks are, however, crucial and had to be added as 
Table 2. Presentation of the total area (ha) occupied by each mangrove species with the whole studied area (TMA) and the total area occupied by each mangrove species within the inundation classes at present $(\mathrm{TMAI}) . \mathrm{Sw}=$ seaward side and $\mathrm{Lw}=$ landward side.

\begin{tabular}{lccc}
\hline Species & TMA & TMAI & Difference $(\%)$ \\
\hline Avicennia marina $\mathrm{Sw}$ & 46.59 & 41.65 & 11.86 \\
Avicennia marina $\mathrm{Lw}$ & 32.34 & 29.53 & 9.52 \\
Ceriops tagal Lw & 37.99 & 36.53 & 3.99 \\
Ceriops tagal $\mathrm{Sw}$ & 13.50 & 13.27 & 1.76 \\
Rhizophora mucronata & 109.42 & 105.50 & 3.71 \\
Sonneratia alba & 7.96 & 4.95 & 60.89 \\
\hline
\end{tabular}

estimates (based on measurements within the creek) due to high mangrove coverage. Absolute mean error and standard deviation for densely covered and less densely covered areas are $0.013 \mathrm{~m} \pm 0.106$ and $0.089 \mathrm{~m} \pm 0.374$, respectively.

\subsection{Simulation of sea level rise scenarios}

The current situation covers a total (studied) area of 423.43 ha, of which the regularly flooded area and the nonflooded area encompass 386.53 and 36.90 ha, respectively. When looking at the inundation classes within the different scenarios (Fig. 2C1 to C5), we can conclude that there is an overall trend of transgression into the terrestrial areas. The maximum scenario in particular $(+88 \mathrm{~cm})$ represents a significant area increase of class 0 and class 1 (AHT) (for abbreviations, see Fig. 2c). More specifically, the percentage area increase of these two classes from the current situation towards the maximum scenario of SLR is 245 and $103 \%$, respectively. After calculating the extent of each mangrove species within each current inundation class, KolmogorovSmirnov tests were completed with results showing significance values $<0.05$ for each species. The vegetation distribution is therefore not normal and nonparametric techniques have to be used for further analyses. The following Kruskal-Wallis test proved that the distribution of the vegetation within the inundation classes is not random; all significance values are $<0.05$. Each species evaluated within the area has a preference for certain inundation classes, confirming the occurrence of a specific zonation or spatial structure in Gazi Bay and therefore also an adequate accuracy of the field measurements.

Due to the errors on the classification of the vegetation map (see Sect. 2.1 and Neukermans et al., 2008) and the topographical measurements, the total area (ha) occupied by each mangrove species within the whole study area (TMA) does not fully coincide with the total area (ha) occupied by each mangrove species within the inundation classes at present (TMAI). This, however, does not exceed values between 2 and 12 (Table 2), except for Sonneratia alba, which mainly occurs in class $0(38 \%)$ and class 1 (AHT) $(35 \%)$, consequently being the only species with a high difference

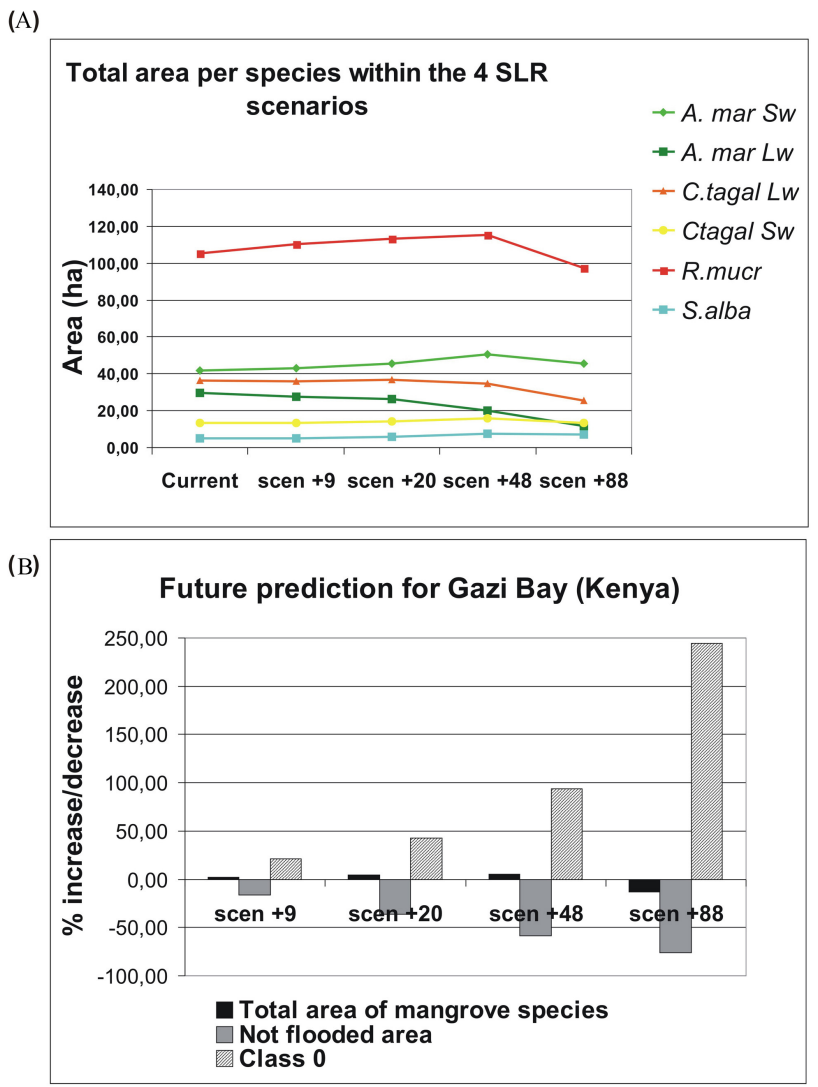

Fig. 3. (A) Graph of the total area (ha) per species within the four SLR scenarios, (B) future prediction of the dynamics of mangroves, non-flooded area and class 0 .

between TMA and TMAI of $61 \%$. The high discrepancy between TMA and TMAI for $S$. alba could be explained by a possible lower accuracy of the DTM at the breaklines marking the creek bank.

All other species appear to have an adequate distribution within the whole study area: Avicennia marina Sw (seaward) mainly resides in class 1 (AHT) $(26 \%)$ and class 2 (MHT) (45\%), Rhizophora mucronata mainly appears in class 2 (MHT) (53\%) and class 3 (NHT) (22\%), whilst Ceriops ta$\mathrm{gal}$, which is an inner mangrove, occupies the areas in several mid-classes. A. marina Lw (landward) dominates the landward classes with $35 \%$ in class 4 (SHT). An extrapolation of changes in vegetation assemblages towards future scenarios (Fig. 3a) demonstrates that, in comparison to the average scenario of SLR $(+48 \mathrm{~cm})$, all species will decrease in the maximum scenario $(+88 \mathrm{~cm})$, resulting in a decline of $13 \%$ in $100 \mathrm{yr}$. Although most species show a possible area increase throughout the minimum, relative and average scenario, this is not the case for A. marina Lw, as this species will diminish throughout all scenarios, with a highest decrease of $60 \%$ in the maximum scenario. When considering the two socioeconomically most important species $R$. mucronata and $C$. tagal in the most probable relative scenario of $+20 \mathrm{~cm}$ SLR, 
an area increase of $15 \%$ occurs in comparison to the current situation. Finally, the area proportions between the total mangrove area, the non-flooded area and class 0 are shown in Fig. $3 b$ as percentage increase or decrease compared to the current situation. The maximum scenario shows a considerable decrease in total mangrove area of $13 \%$, whereas for the relative scenario this area increases by $4 \%$. The most marked increase is for the area of class 0 , namely $245 \%$ in comparison to the current situation.

\subsection{Sensitivity analysis and error matrix for map comparison or accuracy assessment}

Table B1 (see Appendix B) shows the results of the error matrices for map comparison or accuracy assessment. When comparing the vegetation distribution within adjusted height boundaries for each inundation class, the outcome appears to be relatively sensitive to an increase or decrease of $15 \%$. The overall accuracy, with a comparable outcome for $K_{\text {hat }}$, fluctuates between 87.34 and $65.88 \%$ when considering an increase or decrease up to $10 \%$, yet strongly declines towards 53.61 to $48.02 \%$ when height boundaries of each inundation class are adjusted by $15 \%$. As the applied vegetation classification confirms the occurrence of a specific zonation or spatial structure in Gazi Bay, which is highly related to inundation patterns, we can conclude that sensitivity to alterations in topography can be significant from a certain limit and should therefore be aligned to vegetation distributions when data are available. Furthermore, the wind setup may have affected the high-water-line measurements at spring tide. In addition, the inundation classification according to Watson (1928), which is based on inundation frequency, may not always yield fully satisfactory results, especially in regions with an irregular tidal regime and/or irregular elevation profile, where the duration of inundation seems equally important, as was shown by Van Loon et al. (2007).

\section{Discussion}

This study was to investigate whether mangrove assemblages in Gazi Bay have the potential to migrate to more landward areas, which can contribute to their resilience to SLR (Fig. 4), understood as the survival of the formation within the site. Although the focus of this study was mainly on tidal range, we emphasise the importance of sediment supply, es-

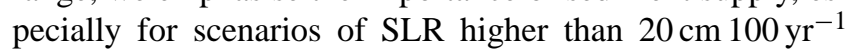
(relative scenario). Whether mangroves can be resilient to SLR strongly depends on the physiographic setting in which these ecosystems occur, human activities that are carried out in the wetland and on how species-specific competition and adaptation will unfold. There is no clear-cut answer that can be applied to global mangrove coverage; however, by studying this particular mangrove area with a mesotidal regime and a common vegetation zonation along a gentle slope gra- dient from land to sea, extrapolations can be made to areas with similar characteristics.

\subsection{Vegetation dynamics of mangrove assemblages under different scenarios of SLR}

Bearing in mind the reductionistic approach, the extent of the most common assemblages, apart from Avicennia marina and Ceriops tagal on the landward side (Lw), are forecasted to increase in surface under the different scenarios of SLR (except for the maximum scenario of $+88 \mathrm{~cm}$ ). This forecast is in line with a few earlier reports that current sea level rise rates do not pose a threat to mangrove ecosystems (e.g. McKee et al. 2007; Snedaker et al., 1994; Tan and Zhang, 1997), but contradicts many others (e.g. Ellison and Stoddart, 1991; Fujimoto and Miyagi 1990; Parkinson et al., 1994; Pernetta, 1993). However, considering the uncertainties regarding the impact of global change on mangrove growth and development, such contradictions are not unexpected. In addition, our reductionistic approach focuses on tidal range and the possible dispersal range of propagules, but it does not take into account the biogeomorphological capacity to maintain or to protect a mangrove forest.

Landward migration of mangroves in Gazi Bay appears to be limited under the maximum scenario as the highest intertidal inundation class strongly decreases due to the topographical settings at the edge of the inhabited area. Consequently, the coastal squeeze will signify a decrease in the Avicennia-dominated assemblages if they fail to adapt to a more frequent inundation or if competition with other species prevails. Dahdouh-Guebas et al. (2004a) made a prediction of future vegetation structure in Gazi Bay based on retrospective remote sensing, social surveys and tree distribution, and results show that the surface extent of A. marina on the landward side has been reducing since 1972. Furthermore, the current situation in Gazi Bay is characterised by large bare and sandy sites on the landward side which have remained in the same state for a substantial time; that is, we have observed no colonisation for at least $16 \mathrm{yr}$ ). When landward areas are accessible during SLR, dispersal and early growth become important stages in a plant life that fundamentally determine community structure and population dynamics (Clarke et al., 2001; Sousa et al., 2007). These processes are very complex. A dense mangrove forest can provide an adequate propagule supply for dispersal towards newly colonisable areas, but (1) as Clarke et al. (2001) stated, establishment of young trees is mainly related to the presence of parental trees, while this is not so much the case for juveniles and the hydrochorous dispersal of propagules, and (2) suitability for stranding or self-planting of propagules is strongly dependent on the presence of root structures (which can facilitate the entanglement of propagules) and the compactness of the soil (clay- or siltdominated) (Di Nitto et al., 2008).

As in other transitional systems, plant establishment and community succession is driven by tolerance to physiological 


\section{MANGROVES FACING SEA LEVEL RISE}

Case study: Gazi Bay, Kenya

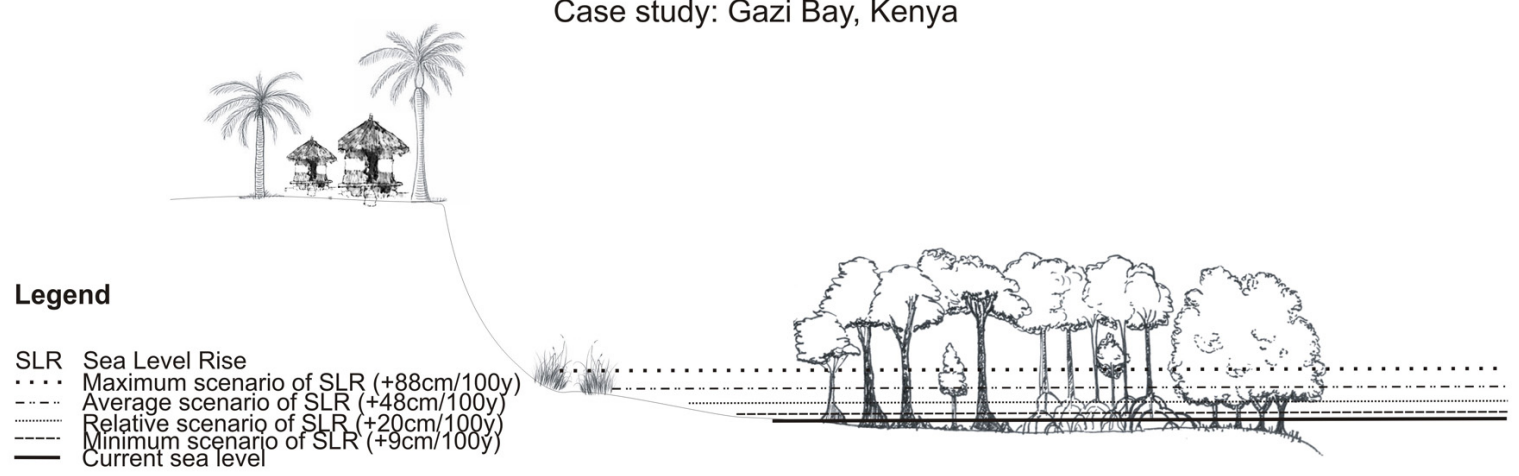

Are mangroves resilient to sea level rise?

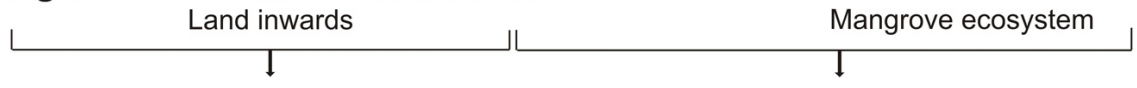

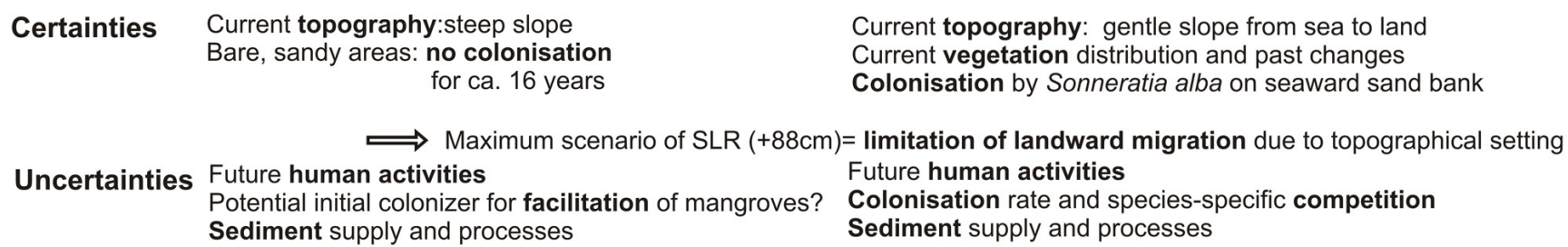

$\Longrightarrow$ Educated guess: possibility exists for adaptation to SLR

$\Longrightarrow$ Need for ADAPTIVE CONSERVATION MANAGEMENT on a regional scale

Fig. 4. Overview scheme summarising the discussion on resilience of mangroves facing sea level rise, more specifically concerning the case study in Gazi Bay (Kenya).

stress and plant-plant interactions (Bertness, 1991; Milbrandt and Tinsley, 2006); hence species-specific competition could signify a natural blockage for landward migration of mangroves. However, in several cases, facilitation is a common mechanism of succession in terrestrial habitats, meaning that an early coloniser changes the abiotic conditions in a way that allows an entry and finally a displacement of a second species to a previous intolerable habitat (Connell and Slayter, 1977). This was, for instance, the case for (1) saltwort (Batis maritima L.), as it was identified as an abundant initial coloniser of an extensive black mangrove (Avicennia germinans L.) die-off area (Milbrandt and Rinsley, 2006), and (2) salt marsh cordgrass (Spartina alterniflora Loisel.), being a potential initial soil stabiliser creating successional stages firstly for Laguncularia racemosa (L.) C. F. Gaertn, which is secondly outshaded and replaced by Avicennia schaueriana Stapf and Leechm. ex Mold. (CunhaLignon et al., 2009).
The reported forecasts can also have an important socioecological implication. Although the forest adjacent to the village has long been overexploited for wood and decreased in area, anthropogenic disturbance has diminished over the last years and some mangrove assemblages have even expanded (Dahdouh-Guebas et al., 2004a). An increase in mangrove area under different scenarios of SLR, provided that it does not go at the expense of qualitative degradation, may imply an increase in anthropogenic threats such as traditional utilisation (McLeod and Salm, 2006). Clear felling of mangroves species can have severe consequences for future vegetation dynamics. Furthermore, most mangrove creeks (like the case in Gazi Bay) are characterised by the occurrence of time-velocity asymmetry in which ebb flow is more dominant than flood flow (Kitheka 1997, 1998; Kitheka et al., 2002). Sediment trapping occurs during incoming flood tides, and there is no significant export of sediments during ebb tide (Furukawa and Wolanski, 1996; Wattayakorn et al., 1990); however degradation of mangroves can lower trapping efficiency (Kitheka et al., 2002), consequently increasing vulnerability to sea level rise. 


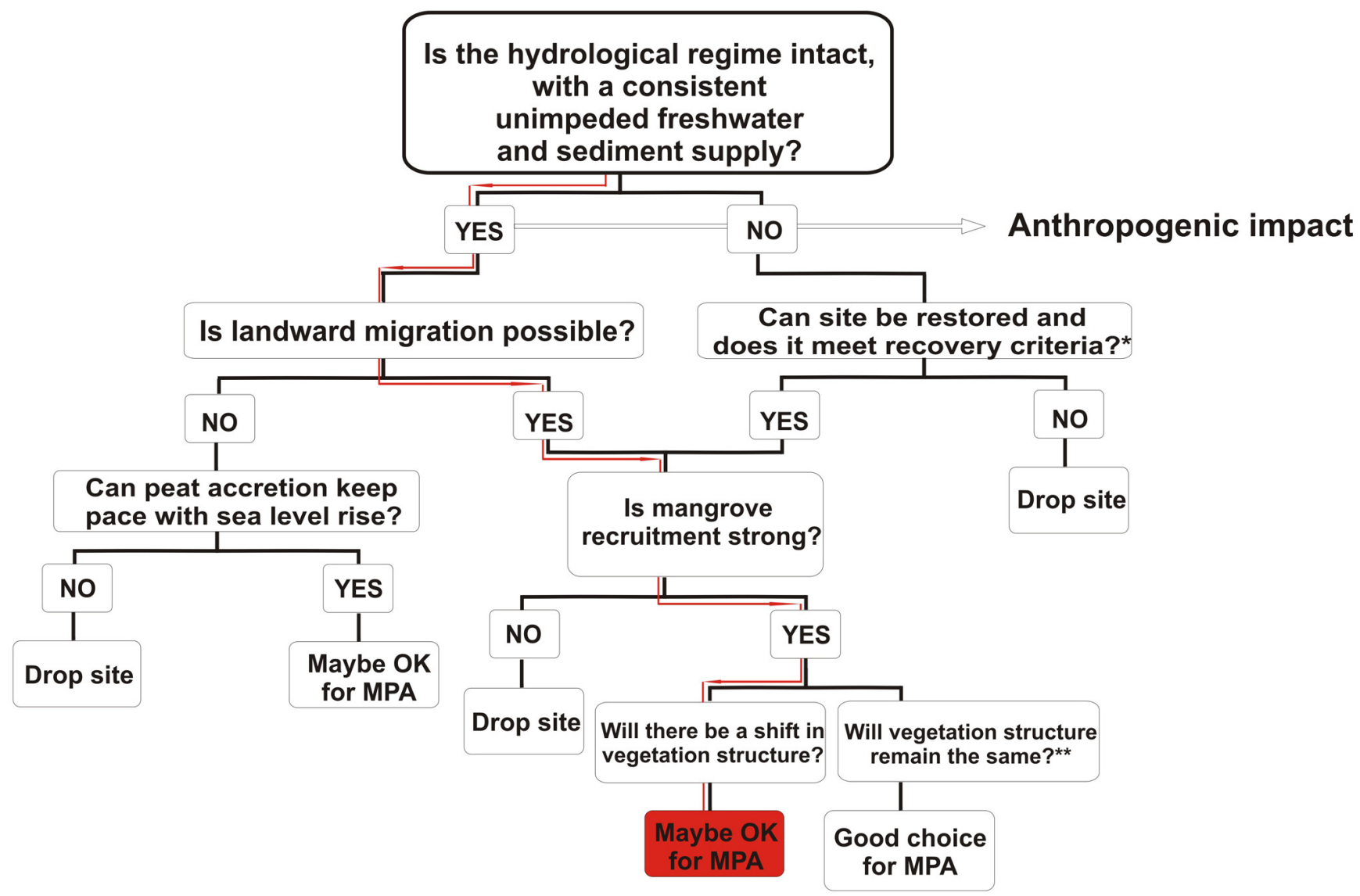

Fig. 5. Decision tree to aid resilient site selection for mangroves according to McLeod and Salm (2006). This three can be applied once candidate sites of high biodiversity have been selected using biological criteria, for instance *, factors that indicate strong recovery potential (see Appendix Table C1). This decision tree was adjusted $(* *)$ to implement the possibility of a shift in vegetation structure. MPA $=$ marine protected area.

\subsection{Vegetation dynamics of individual species under different scenarios of SLR}

When landward areas become accessible for the migration and colonisation of mangrove species, we have to ask the same question as Alongi (p4, 2008): "Are trends in mangrove forest replacement in response to catastrophic disturbances the result of somewhat deterministic sequences as in terrestrial forests, or are they the result of a stochastic "first come, first served" opportunistic response or neither?" Empirical data support the idea that recovery is stochastic with distinct succession stages, yet early sequences of species replacement are greatly influenced by species present at initial recovery (Alongi, 2008; Clarke et al., 2001; Sousa et al., 2007). Within this study the extrapolation of the present vegetation distribution towards scenarios under a rising sea level is based on species-specific preference for certain inundation frequencies. The survival of these species in their shift in a more landward direction is strongly dependent on their colonisation rate and interspecific competition. The most seaward mangrove species Sonneratia alba appears in vege- tation zones that are daily inundated and are never submitted to large salinity variations (Tomlinson, 1986). When sea level rises, this species is forecasted to increase in area (except under the maximum scenario), yet as investigated by DahdouhGuebas et al. (2004a), the juvenile layer within these $S$. alba stands is limited and propagule establishment is hampered by currents that are generally known to be strongest along the seaward side (Diop et al., 2001). The distribution of the young individuals of $S$. alba is more related to the adult trees, whereas juveniles are generally spread over a wider area (Dahdouh-Guebas et al., 2004a). The latter also applies for the species Avicennia marina on the seaward side $(\mathrm{Sw})$. Furthermore, Imai et al. (2006) verified that $S$. alba seedlings and saplings, which require sunny conditions for their growth, were more abundant in gaps than in the understorey. Competition with a more landward species such as Rhizophora mucronata might demonstrate that an area increase of $S$. alba could be overestimated by our analyses. However, colonisation by $S$. alba on seaward sand banks has occurred throughout the years. Additionally, bearing in 
mind the site-specific rates of sea level rise and sediment input rates, Ellison and Stoddart (1991) claimed that mangrove ecosystems can keep pace with SLR of $8-9 \mathrm{~cm}$ per $100 \mathrm{yr}$, making seaward expansion and colonisation of these daily inundated areas possible. Rates of $9-12 \mathrm{~cm}$ per $100 \mathrm{yr}$ will cause stress, yet the ability for mangroves to adjust to even higher rates is unlikely. The minimum scenario of SLR $(+9 \mathrm{~cm})$ could in fact provide an additional and suitable habitat for $S$. alba and A. marina ( $\mathrm{Sw}$ ).

R. mucronata and Ceriops tagal are two economically valuable pioneer species that will most likely increase as predicted unless anthropogenic impact rises. Multivariate vegetation structure analysis showed that $C$. tagal is very abundant in the understorey of assemblages dominated by other mangroves, which could mask a dynamic shift (DahdouhGuebas et al., 2004a). $R$. mucronata and C. tagal already occupy the mid-zone within the mangrove area and knowledge on the dispersal of their propagules indicates that prop roots and pencil roots clearly have the ability to entangle propagules and that preference of propagule dispersal goes to flat areas and substrates with a more compact soil structure (clay, silt) (Di Nitto et al., 2008). One disadvantage for $R$. mucronata could, however, be represented by a further siltation along the seaward sand bank creating a patch of arid conditions and higher light intensity more favourable for $A$. marina (Dahdouh-Guebas, et al. 2004a).

Avicennia marina $(\mathrm{Lw})$ will have to adapt to greater inundation frequencies. It is known that this species can tolerate high salinity variation, so could the double zonation of this species on the landward side versus the same species on the seaward side support the idea of dynamic adaptation? Genetic analyses based on 48 RAPD (randomly amplified polymorphic DNA) loci have demonstrated that four DNA fragments show a slight differentiation in allelic frequency between the two A. marina stands in spite of their short distance separation (Dahdouh-Guebas et al., 2004b). This indicates that there is less genetic exchange between the disjunctive stands than within one stand, consequently suggesting that an ecological or physical barrier might exist. Tidal range might facilitate the dispersal of propagules in both directions; however obstruction by complex root structures can prevent this exchange. Additionally, interspecific competition with the adjacent species $C$. tagal could disadvantage $A$. marina as McCusker (1977) confirms that a salinity increase causes a reduction in water use efficiency for the seedlings of Rhizophora, but not for Ceriops. Furthermore, an elevated $\mathrm{CO}_{2}$ level will enhance the efficiency of water use (UNEP, 1994); however this advantage is lost when salinity becomes too high, for instance, at low inundation frequency areas on the landward side. Another drawback for A. marina is an increase of temperature, since this species has lowest optimal temperature for leaf development (Hutchings and Saenger, 1987).

There are several well-established physiologic mechanisms influencing mangrove community composition (Duke et al., 1998; McKee, 1995), yet research is needed on interspecies interactions influencing mangrove forest regeneration in post-disturbance mangrove communities.

\subsection{Recommendation for further research and management strategies}

In the light of mangrove ecosystem stresses caused by climate change, managers face the dual challenge of selecting and implementing conservation strategies in order to maintain and restore resilient mangrove forests.

In this study the emphasis resides on tidal range and not on sediment supply; however, we give a preliminary vulnerability assessment of this mangrove area based on a slightly adjusted decision tree (Fig. 5) to aid resilient site selection for mangroves by McLeod and Salm (2006). This decision tree was applied after appointing Gazi Bay as a high biodiversity candidate site based on biological and environmental criteria (Table C1; see Appendix C). Decisions were made based on the available literature involving the mangrove area in Gazi Bay and the relative SLR scenario of $+20 \mathrm{~cm}$, which coincides with the current trend along the coast of Kenyan.

Following this decision tree, the mangrove area in Gazi Bay appears to be adequately resilient for at least $100 \mathrm{yr}$ and can most likely be appointed as a marine protected area (MPA). However, although we do not intend to focus only on MPAs, we want to anticipate a future scenario of sea level rise and indicate gaps in, on the one hand, scientific and, on the other hand, site-specific knowledge that necessitate further research. Given (1) the mesotidal regime and permanent rivers and creeks that provide freshwater and sediment (mainly during wet season), (2) the knowledge that the drainage basin of both Mkurumuji and Kidogoweni rivers, which extend into the coastal ranges of the Shimba Hills National Reserve, has limited anthropogenic pressures with respect to the intactness of the hydrological regime, and given that (3) landward migration in Gazi Bay is possible under the relative scenario of sea level rise, the decision tree leads us towards the question whether recruitment is strong. The answer is definitely "yes"; however we feel that the possibility of a shift in vegetation structure needs to be implemented, rendering Gazi Bay a site that is "Maybe OK for MPA". According to McLeod and Salm (2006) the decision tree would have led towards "Good choice for MPA".

The recommendations for further research and management strategies, which can be applied globally, are the following: (1) identifying an early coloniser to promote early establishment of mangrove seedlings, (2) measuring changes in elevation by means of surface elevation tables (SETs), (3) assuring the possibility of landward migration and (4) investigating propagule dispersal by combined hydrodynamic and ecological behaviour modelling. 


\section{Appendix A}

\section{Calculation of an error matrix for map comparison or accuracy assessment}

- Map 1 is a raster grid of $n$ classes as a model output

- Map 2 is a raster grid of $n$ classes from an alternative model or comparison reference layer.

Producer's accuracy (PA)

Producer's accuracy (PA): Takes into account the accuracy of individual classes and therefore indicates the probability of the cell value in Map 2 being the same as in Map 1.

$\mathrm{PA}=x_{i i} / x_{+i} \cdot 100 \%$

$x_{i i}=$ total number of correct cells in a class

$x_{+i}=$ sum of cell values in the column

User's accuracy (UA): Takes into account the accuracy of individual classes but indicates the probability of the cell value in Map 1 being the same as in Map 2.

$\mathrm{UA}=x_{i i} / x_{\mathrm{i}+} \cdot 100 \%$

$x_{i i}=$ total number of correct cells in a class

$x_{\mathrm{i}+}=$ sum of cell values in the row

Overall Accuracy (OA): Summarizes the total agreement/disagreement between the maps and incorporates the major diagonal while excluding the omission and the commission errors.

$\mathrm{OA}=D / N \cdot 100 \%$

$D=$ total number correct cells as summed along

the major diagonal

$N=$ total number of cells in the error matrix
Table B1. Results of the error matrices for map comparison or accuracy assessment when comparing the vegetation distribution within adjusted height boundaries for the inundation classes. Values represent the overall accuracy and $K_{\text {hat }}$ in percentages.

\begin{tabular}{llcc}
\hline $\begin{array}{l}\text { Input } \\
\text { parameter }\end{array}$ & $\begin{array}{l}\text { Adjustments } \\
\text { in input criteria }\end{array}$ & \multicolumn{2}{c}{$\begin{array}{l}\text { Comparison of vegetation distributions } \\
\text { within the adjusted inundation classes }\end{array}$} \\
\hline & & $\begin{array}{c}\text { Overall accuracy } \\
(\%)\end{array}$ & $\begin{array}{c}K_{\text {hat }} \\
(\%)\end{array}$ \\
\hline Inundation & $+5 \%$ & 87.34 & 85.34 \\
classes & $+10 \%$ & 76.67 & 75.31 \\
(height & $+15 \%$ & 48.02 & 49.61 \\
boundaries) & $-5 \%$ & 78.09 & 75.28 \\
& $-10 \%$ & 65.88 & 65.39 \\
& $-15 \%$ & 53.61 & 50.72 \\
\hline
\end{tabular}

$N=$ total number of cells in the error matrix

$K_{\text {hat }}$ : Measure of agreement or accuracy based on KAPPA analysis to compare maps of similar categories in order to determine if they are significantly different

$K_{\text {hat }}=N\left(\frac{\left(\sum_{i=1}^{r} x_{i i}-\sum_{i=1}^{r}\left(x_{i+} \cdot x_{+i}\right)\right)}{\left(N^{2}-\sum_{i=1}^{r}\left(x_{i+} \cdot x_{+i}\right)\right)}\right)$

$r=$ number of rows in the matrix

$x_{i i}=$ total number correct cells in a class

(i.e. value in row $i$ and column $i$ )

$x_{i+}=$ total for row $i$

$x_{+i}=$ total for column $i$ 
Table C1. Mangrove resilience factors that contribute to site selection (according to McLeod and Salm, 2006). Case study: Gazi Bay, Kenya.

\begin{tabular}{|c|c|c|}
\hline Factors that allow for peat building to keep up with sea level rise & Applicable to Gazi Bay Yes/No & Literature available per factor \\
\hline $\begin{array}{l}\text { Association with drainage systems including permanent rivers and } \\
\text { creeks that provide freshwater and sediment }\end{array}$ & Yes & $\begin{array}{l}\text { e.g. Dahdouh-Guebas et al. } \\
\text { (2004a), Kitheka (1996, 1997), } \\
\text { Njambuya (2006), Obade et al. } \\
\text { (2004), Ohowa et al. (1997) }\end{array}$ \\
\hline
\end{tabular}

bution and accretion

Actively prograding coast and delta Yes

Natural features (bays, barrier islands, beaches, sandbars, reefs) that re- Yes

duce wave erosion and storm surge

Factors that allow for landward migration

Mangroves backed by low-lying retreat areas (for example, salt flats, No/Yes in certain places marshes, coastal plains) which may provide suitable habitat for colonisation and landward movement of mangroves as sea level rises Mangroves in remote areas and distant from human settlements and Yes agriculture, aquaculture, and salt production developments

Mangroves in areas where abandoned alternate land use provides opportunities for restoration, for example, flooded villages, tsunami-prone land, unproductive ponds

Factors that enhance sediment distribution and propagule dispersal

Unencumbered tidal creeks and areas with a large tidal range to im- Yes prove flushing, reduce ponding and stagnation, and enhance sediment distribution and propagule dispersal

Areas with a large tidal range that may be better able to adjust to in- Yes creases in sea level due to stress tolerance

Permanent strong currents to redistribute sediment and maintain open Yes channels

Factors that indicate survival over time

Diverse species assemblage and clear zonation over range of elevation Yes (intertidal to dry land) e.g. Di Nitto et al. (2008), Neukermans et al. (2008), Obade et al. (2004)

Yes, unmanaged coconut plantations e.g. De Ryck (2009), Di Nitto et al. (2008), Kitheka (1996, 1997), Ohowa et al. (1997)

Range in size from new recruits to maximum size class (location and Yes species dependent)

Tidal creek and channel banks consolidated by continuous dense man- Yes grove forest (which will keep these channels open)

Healthy mangrove systems in areas which have been exposed to large No increases in sea level due to climate-induced sea level rise and tectonic subsidence

Factors that indicate strong recovery potential

Access to healthy supply of propagules, either internally or from adja- Yes cent mangrove areas

Strong mangrove recruitment indicated by the presence, variety, and Yes abundance of established mangrove propagules

Close proximity and connectivity to neighbouring stands of healthy Yes mangroves

Access to sediment and freshwater

Limited anthropogenic stress

Unimpeded or easily restorable hydrological regime

Effective management regime in place such as the control of usual threats like dredging and filling, conversion to aquaculture ponds, and construction of dams, roads, and dikes that disrupt hydrological regime, etc.

Integrated coastal management plan or protected area management plan Yes/No

implemented

e.g. Beeckman et al. (1989), Bosire et al. (2008a), Bosire et al. (2006), Dahdouh-Guebas et al. (2002a), Dahdouh-Guebas et al. (2004a), Dahdouh-Guebas et al. (2002b), Kairo (2001), Kairo et al. (2001), Neukermans et al. (2008), Tack et al. (1992), Van Tendeloo (2004)
Yes

Yes, no major residential area in the vicinity, selected as a fairly pristine East African site in the EU PUMPSEA project: http://www.pumpsea.icat.fc.ul. pt/main.php

Yes

Yes

www.biogeosciences.net/11/857/2014/ 
Acknowledgements. Many thanks are due to the people of Gazi Bay, more specifically Latifa S. Ba'alawy and her relatives for the hospitable family environment and R. Abdul for the assistance on the field. This research was funded the Flemish Interuniversity Council (VLIR) and the Fonds David \& Alice Van Buuren. D. D. is the recipient of a VLIR PhD scholarship. This work was presented in part at (1) the International Symposium of Aquatic Vascular Plants (ISAVP) (January 11-13, 2006, Brussels, Belgium) (2) the 7th International Symposium on GIS and Computer Cartography for Coastal Zone Management (CoastGIS) (July 12-16, 2006, Wollongong, Australia) and the (3) MMM3 Meeting on Mangrove ecology, functioning and Management (2-6 July 2012, Galle, Sri Lanka).

Edited by: B. Satyanarayana

\section{References}

Abuodha, P. A. W. and Kairo, J. G.: Human-induced stresses on mangrove swamps along the Kenyan coast, Hydrobiologia, 458, 255-265, 2001.

Allen, J. A. and Krauss, K. W.: Influence of propagule flotation longevity and light availability on establishment of introduced mangrove species in Hawaii, Pacific Science, 60, 367-376, 2006.

Alongi, D. M.: Present state and future of the world's mangrove forests, Environ. Conserv., 29, 331-349, 2002.

Barbier, E. B.: Habitat-fishery linkages and mangrove loss in Thailand, Contemporary Economic Policy, 21, 59-77, 2003.

Beeckman, H., Gallin, E., and Coppejans, E.: Indirect gradient analysis of the mangal formation of Gazi Bay (Kenya), Silva Gandavensis, 54, 57-72, 1989.

Bertness, M. D.: Interspecific interactions among high marsh perennials in a New England salt marsh, J. Ecol., 72, 125-137, 1991.

Bosire, J., Kairo, J. G., Kazungu, J., Koedam, N., and DahdouhGuebas, F.: Spatial and temporal regeneration dynamics in Ceriops tagal (Perr.) C.B. Rob. (Rhizophoraceae) mangrove forests in Kenya, Western Indian Ocean Journal of Marine Science , 7, 69-80, 2008a.

Bosire, J. O., Dahdouh-Guebas, F., Kairo, J. G., and Koedam, N.: Colonization of non-planted mangrove species into restored mangrove stands in Gazi Bay, Kenya, Aquat. Bot., 76, 267-279, 2003.

Bosire, J. O., Dahdouh-Guebas, F., Kairo, J. G., Wartel, S., Kazungu, J., and Koedam, N.: Success rates of recruited tree species and their contribution to the structural development of reforested mangrove stands, Mar. Ecol. Prog. Ser., 325, 85-91, 2006.

Bosire, J. O., Dahdouh-Guebas, F., Walton, M., Crona, B. I., Lewis, R. R., Field, C., Kairo, J. G., and Koedam, N.: Functionality of restored mangroves, A review, Aquatic Botany, 89, 251-259, 2008b.

Cahoon, D. R., Hensel, P. F., Spencer, T., Reed, D. J., McKee, K. L., and Saintilan, N.: Coastal wetland vulnerability to relative sealevel rise, Wetland elevation trends and process controls, Ecol. Stu. An., 190, 271-292, 2006.

Clarke, P. J., Kerrigan, R. A., and Westphal, C. J.: Dispersal potential and early growth in 14 tropical mangroves: do early life his- tory traits correlate with patterns of adult distribution?, J. Ecol., 89, 648-659, 2001.

Connell, J. H. and Slayter, R. O.: Mechanisms of succession in natural communities and their role in community stability and organization, Am. Natural., 111, 1119-1144, 1977.

Cunha-Lignon, M., Mahiques, M. M., Schaeffer-Novelli, Y., Rodrigues, M., Klein, D. A., Goya, S. C., Menghini, R. P., Tolentino, C. V., Cintrón-Molero, G., and Dahdouh-Guebas F.: Analysis of mangrove forest succession using cores: a case study in the Cananéia-Iguape Coastal System, São Paulo, Brazil, Braz. J. Oceanogr., 57, 2009.

Dahdouh-Guebas, F. and Koedam, N.: Empirical estimate of the reliability of the use of the Point-Centred Quarter Method (PCQM): Solutions to ambiguous field situations and description of the PCQM+ protocol, Forest Ecol. Manage., 228, 1-18, 2006.

Dahdouh-Guebas, F., Mathenge, C., Kairo, J. G., and Koedam, N.: Utilization of mangrove wood products around Mida Creek (Kenya) amongst subsistence and commercial users, Economic Botany, 54, 513-527, 2000.

Dahdouh-Guebas, F., Kairo, J. G., Jayatissa, L. P., Cannicci, S., and Koedam N.: An ordination study to view vegetation structure dynamics in disturbed and undisturbed mangrove forests in Kenya and Sri Lanka, Plant Ecol., 161, 123-135, 2002a.

Dahdouh-Guebas, F., Van Pottelbergh, I., Kairo, J. G., Cannicci, S., and Koedam, N.: Human-impacted mangroves in Gazi (Kenya): predicting future vegetation based on retrospective remote sensing, social surveys, and tree distribution, Mar. Ecol. Prog. Ser., 272, 77-92, 2004a.

Dahdouh-Guebas, F., Verneirt, M., Cannicci, S., Kairo, J. G., Tack, J. F., and Koedam, N.: An exploratory study on grapsid crab zonation in Kenyan mangroves, Wet. Ecol. Manage., 10, 179187, 2002 b.

Dahdouh-Guebas, F., Jayatissa, L. P., Di Nitto, D., Bosire, J. O., Lo Seen, D., and Koedam, N.: How effective were mangroves as a defence against the recent tsunami?, Current Biol., 15, 13371338, 2005.

Dahdouh-Guebas, F., De Bondt, R., Abeysinghe, P. D., Kairo, J. G., Cannicci, S., Triest, L., and Koedam, N.: Comparative study of the disjunct zonation pattern of the grey mangrove Avicennia marina (Forsk.) Vierh. in Gazi Bay (Kenya), Bull. Mar. Sci., 74, 237-252, 2004b.

De Ryck, D.: Moving and settling: Experiments on the dispersal and establishment of hydrochorous propagules, Master Thesis, Vrije Universiteit Brussel, Brussels, 2009.

Di Nitto, D., Dahdouh-Guebas, F., Kairo, J. G., Decleir, H., and Koedam, N.: Digital terrain modelling to investigate the effects of sea level rise on mangrove propagule establishment, Mar. Ecol. Prog. Ser., 356, 175-188, 2008.

Diop, E. S., Gordon, C., Semesi, A. K., Soumaré, A., Diallo, N., Guissé, A., Diouf, M., and Ayivor, J. S.: Mangoves of Africa in De Lacerda LD, ed., Mangrove ecosystems, Berlin, Germany, Springer-Verlag, 2001.

Doody, J. P.: "Coastal squeeze" - an historical perspective, J. Coast. Conserv., 10/1-2, 129-138, 2004.

Drexler, J. Z.: Maximum longevities of Rhizophora apiculata and R. mucronata propagules, Pacific Science, 55, 17-22, 2001.

Duke, N. C., Ball, M. C., and Ellison, J. C.: Factors influencing biodiversity and distributional gradients in mangroves, Glob. Ecol. Biogeogr. Lett., 7, 27-47, 1988. 
Duke, N. C., Meynecke, J. O., Dittmann, S., Ellison, A. M., Anger, K., Berger, U., Cannicci, S., Diele, K., Ewel, K. C., Field, C. D., Koedam, N., Lee, S. Y., Marchand, C., Nordhaus, I., and Dahdouh-Guebas, F.: A world without mangroves?, Science, 317, 41-42, 2007.

Ellison, J. C. and Stoddart, D. R.: Mangrove ecosystem collapse during predicted sea-level rise - Holocene analogs and implications, J. Coast. Res., 7, 151-165, 1991.

FAO: Status and Trends in Mangrove Area Extent Worldwide, Food and Agricultural Organization of the United Nations, Forest Resources Division, Paris, 2003.

Fujimoto, K. and Miyagi, T.: Late Holocene sea level fluctuations and mangrove forest formation on Ponape Island, Micronesia, J. Geogr., 99, 507-514, 1990.

Furukawa, K. and Wolanski, E.: Sedimentation in mangrove forests, Mangroves and Salt Marshes, 1, 3-10, 1996.

Gallin, E., Coppejans, E., and Beeckman, H.: The mangrove vegetation of Gazi bay (Kenya), Bulletin de la Société Royal Botanique de Belgique, 122, 197-207, 1989.

Gilman, E., Ellison, J., and Coleman, R.: Assessment of mangrove response to projected relative sea-level rise and recent historical reconstruction of shoreline position, 124, 105-130, 2007.

Gilman, E. L., Ellison, J., Duke, N. C., and Field, C.: Threats to mangroves from climate change and adaptation options: A review, Aquat. Botan., 89, 237-250, 2008.

Gilman, E. L., Ellison, J., Jungblat, V., VanLavieren, H., Adler, E., Wilson, L., Areki, F., Brighouse, G., Bungitak, J., Dus, E., Henry, M., Sauni Jr., I., Kilman, M., Matthews, E., Teariki-Ruatu, N., Tukia, S., and Yuknavage, K.: Adapting to Pacific Island mangrove responses to sea level rise and climate change, Clim. Res., 32, 161-176, 2006.

Hutchings, P. A. and Saenger, P.: Ecology of mangroves, St. Lucia, Brisbane, Australia, University of Queensland Press, 1987.

Imai, N., Takyu, M., Nakamura, Y., and Nakamura, T.: Gap formation and regeneration of tropical mangrove forests in Ranong, Thailand, Plant Ecol., 186, 37-46, 2006.

IPCC: Climate Change 2001: The Scientific Basis. Contribution of Working Group I to the Third Assessment Report of the Intergovernmental Panel on Climate Change, Cambridge, United Kingdom and New York, NY, USA, Cambridge University Press, 2001

Kairo, J. G.: Ecology and restoration of mangrove systems in Kenya, PhD dissertation, Vrije Universiteit Brussel, Brussels, Belgium, 2001.

Kairo, J. G., Dahdouh-Guebas, F., Bosire, J., and Koedam, N.: Restoration and management of mangrove systems - a lesson for and from the East African region, S. Afr. J. Bot., 67, 383-389, 2001

Kirui, B. Y. K., Huxham, M., Kairo, J., and Skov, M.: Influence of species richness and environmental context on early survival of replanted mangroves at Gazi Bay, Kenya, Hydrobiol., 603, 171181,2008

Kitheka, J. U.: Water circulation and coastal trapping of brackish water in a tropical mangrove-dominated bay in Kenya, Limnol. Oceanogr., 41, 169-176, 1996.

Kitheka, J. U.: Coastal tidally-driven circulation and the role of water exchange in the linkage between tropical coastal ecosystems, Estuar. Coast. Shelf Sci., 45, 177-187, 1997.
Kitheka, J. U.: Groundwater outflow and its linkage to coastal circulation in a mangrove-fringed creek in Kenya, Estuar. Coast. Shelf Sci., 47, 63-75, 1998.

Kitheka, J. U., Ongwenyi, G. S., and Mavuti, K. M.: Dynamics of suspended sediment exchange and transport in a degraded mangrove creek in Kenya, Ambio, 31, 580-587, 2002.

Krauss, K. W., Allen, J. A., and Cahoon, D. R.: Differential rates of vertical accretion and elevation change among aerial root types in Micronesian mangrove forests, Estuar. Coast. Shelf Sci., 56, 251-259, 2003.

Lopez, C.: Locating some types of random errors in Digital Terrain Models, Int. J. Geogr. Info. Sci., 11, 677-698, 1997.

Lovelock, C. E. and Ellison, J.: Vulnerability of mangroves and associated tidal wetlands of the GBR to climate change, edited by: Johnson, J. and Marshall, P., Climate Change and Great Barrier Reef, Townsville, Australia, Great Barrier Reef Marine Park Authority, 2007.

McCusker, A.: Seedling establishment in mangrove species, Int. J. Trop. Geol. Geogr. Ecol., 1, 23-33, 1977.

McKee, K. L.: Mangrove species distribution and propagule predation in Belize - an exception to the dominance predation hypothesis, Biotropica, 27, 334-345, 1995.

McKee, K. L., Cahoon, D. R., and Feller, I. C.: Caribbean mangroves adjust to rising sea level through biotic controls on change in soil elevation, Glob. Ecol. Biogeogr., 16, 545-556, 2007.

McLeod, E. and Salm, R. V.: Managing Mangroves for Resilience to Climate Change Gland, Switzerland, IUCN, 2006.

Milbrandt, E. C. and Tinsley, M. N.: The role of saltwort (Batis maritima L.) in regeneration of degraded mangrove forests, Hydrobiologia, 568, 369-377, 2006.

Mumby, P. J., Edwards, A. J., Arias-Gonzalez, J. E., Lindeman, K. C., Blackwell, P. G., Gall, A., Gorczynska, M. I., Harborne, A. R., Pescod, C. L., Renken, H., Wabnitz, C. C. C., and Llewellyn, G.: Mangroves enhance the biomass of coral reef fish communities in the Caribbean, Nature, 427, 533-536, 2004.

Nagelkerken, I., Blaber, S. J. M., Bouillon, S., Green, P., Haywood, M., Kirton, L. G., Meynecke, J.-O., Pawlik, J., Penrose, H. M., Sasekumar, A., and Somerfield, P. J.: The habitat function of mangroves for terrestrial and marine fauna: A review, Aquat. Botan., 89, 155-185, 2008.

Neukermans, G., Dahdouh-Guebas, F., Kairo, J. G., and Koedam, N.: Mangrove species and stand mapping in Gazi bay (Kenya) using Quickbird satellite imagery, J. Spat. Sci., 53, 75-86, 2008.

Njambuya, J. W.: Sediment characteristics, its origin and stratigraphy of mangrove soils of Gazi Bay, Kenya, MSc. Environmental Science and Technology Thesis, Vrije Universiteit Brussel, Brussels, Belgium, 2006.

Obade, P., Dahdouh-Guebas, F., Koedam, N., De Wulf, R., and Tack, J. F.: GIS-based integration of interdisciplinary ecological data to detect land-cover changes in creek mangroves at Gazi Bay, Kenya, Western Indian Ocean Journal of Marine Science, 3, 11-27, 2004.

Ohowa, B. O., Mwashote, B. M., and Shimbira, W. S.: Dissolved inorganic nutrient fluxes from seasonal rivers into Gazi Bay, Kenya, Estuar. Coast. Shelf Sci., 45, 189-195, 1997.

Parkinson, R. W., Delaune, R. D., and White, J. R.: Holocene SeaLevel Rise and the Fate of Mangrove Forests within the Wider Caribbean Region, J. Coast. Res., 10, 1077-1086, 1994. 
Pernetta, J. C.: Mangrove forests, climate change and sea-level rise: hydrological influences on community structure and survival, with examples from the Indo-West pacific, Gland, Switzerland, 1993.

Rogers, K., Saintilan, N., and Heijnis, H.: Mangrove encroachment of salt marsh in Western Port Bay, Victoria: The role of sedimentation, subsidence, and sea level rise, Estuaries, 28, 551-559, 2005.

Snedaker, S. C., Meeder, J. F., Ross, M. S., and Ford, R. G.: Mangrove ecosystem collapse during predicted sea-level rise Holocene analogues and implications - discussion, J. Coast. Res., Special Issue, 10, 497-498, 1994.

Sousa, W. P., Kennedy, P. G., Mitchell, B. J., and Ordonez, B. M.: Supply-side ecology in mangroves: Do propagule dispersal and seedling establishment explain forest structure?, Ecol. Monogr., 77, 53-76, 2007.

Stieglitz, T. and Ridd, P. V.: Trapping of mangrove propagules due to density-driven secondary circulation in the Normanby River estuary, NE Australia, Mar. Ecol. Prog. Ser., 211, 131-142, 2001.

Tack, J. F., Vanden Berghe, E., and Polk, P.: Ecomorphology of Crassostrea cucullata (Born, 1778) (Ostreidae) in a mangrove creek (Gazi, Kenya), Hydrobiologia, 247, 109-117, 1992.

Tan, X. and Zhang, Q.: Mangrove beaches' accretion rate and effects of relative sea level rise on mangroves in China, Mar. Sci. Bull., 16, 29-35, 1997.

Tomlinson, P. B.: The Botany of Mangroves, Cambridge, Cambridge University Press, 1986.

UNEP: Assessment and monitoring of climatic change impacts on mangrove ecosystems, UNEP, Regional Seas Reports and Studies, Nairobi, Kenya, Report No. 154, 1994.

Valiela, I., Bowen, J. L., and York, J. K.: Mangrove forests: One of the world's threatened major tropical environments, Bioscience, $51,807-815,2001$.
Van Loon, A. F., Dijksma, R., and Van Mensvoort, M. E .F.: Hydrological classification in mangrove areas: A case study in Can Gio, Vietnam, Aquatic Botany, 87, 80-82, 2007.

Van Tendeloo, A.: Veranderingen in traditionele en commerciële mens-ecosysteemrelaties in de mangrovebaai van Gazi (Kenya): etnobiologie, percepties van de lokale gemeenschap en ecotoeristische activiteiten, Lic./MSc, Biologie thesis, Vrije Universiteit Brussel, Brussel, Belgium, 2004.

Vincente, V. P.: Ecological effects of sea-level rise and sea surface temperature on mangroves, coral reefs, seagrass beds and sandy beaches of Puerto Rico: A preliminary evaluation, ScienceCiencia 16, 1989.

Walters, B. B., Ronnback, P., Kovacs, J. M., Crona, B., Hussain, S. A., Badola, R., Primavera, J. H., Barbier, E., and DahdouhGuebas, F.: Ethnobiology, socio-economics and management of mangrove forests: A review, Aquat. Botan., 89, 220-236, 2008.

Watson, J. G.: Mangrove forests of the Malay Peninsula, Malayan Forest Records, 6, 1-275, 1928.

Wattayakorn, G., Wolanski, E., and Kjerfve, B.: Mixing, trapping and outwelling in the Klong Ngao mangrove swamp, Thailand, Estuar. Coast. Shelf Sci., 31, 667-688, 1990.

Wells, S., Ravilous, C., and Corcoran, E.: In the front line: Shoreline protection and other ecosystem services from mangroves and coraf reefs. Cambridge, UK: United Nations Environment Programme World Conservation Monitoring Centre, 2006.

Wolanski, E. and Chappell, J.: The respons of tropical Australian estuaries to sea level rise, J. Mar. Syst., 7, 267-279, 1996.

Woodroffe, C. D.: The impact of sea-level rise on mangrove shorelines, Progress in Physical Geography, 14, 483-520, 1990.

Woodroffe, C. D. and Grime, D.: Storm impact and evolution of a mangrove-fringed chenier plain, Shoal Bay, Darwin, Australia, Mar. Geol., 159, 303-321, 1999. 